\title{
O PRINCÍPIO DA INSIGNIFICÂNCIA... DO RÉU ${ }^{1}$
}

\author{
THE PRINCIPLE OF THE INSIGNIFICANCE... \\ OF THE DEFENDANT
}

\author{
THIAGO FABRES DE CARVALHO ${ }^{2}$ \\ ISRAEL DOMINGOS JORIO ${ }^{3}$
}

\begin{abstract}
RESUMO: Temos um sistema penal cuja extrema brutalidade comprova o desprezo dos direitos e garantias constitucionais mais elementares. O tratamento massacrante conferido antes e durante o processo, associado à imposição de penas cumpridas sem as mínimas condições de salubridade e dignidade, somente se explica a partir da noção da coisificação do réu, isto é, da negação de sua condição humana. O breve exame da legislação e a mais simples observação das realidades processual e carcerária certamente demonstrarão que o acusado não apenas vem sendo considerado como uma coisa, mas como uma coisa insignificante. Para alterar essa lastimável perspectiva, duas providências se impõem: é preciso enxergar o caráter essencial-mente violento do sistema penal e, em seguida, romper com a alienação criminogênica que nos impede de reconhecer no autor do crime um semelhante, isto é, um ser humano vivo.

PALAVRAS-CHAVE: Sistema Penal; Humanização; Coisificação; Vingança; Sacrifício.
\end{abstract}

ABSTRACT: We deal with a penal system whose extreme brutality proves the contempt of the most elementary constitutional rights. The mortifying treatment given before and during the process, associated with the imposition of sentences that will be served without the very basic health and dignity conditions, can only be explained since the notion of reification of the defendant, i.e., the denial of their humanity. The brief review of our legislation and the simplest observation of the realities of the criminal process and the prison environment will certainly prove that the defendant not only is being considered as a thing, but as something insignificant. To change this perspective, two measures are imperative: we must acknowledge the essentially violent nature of the penal system and, then, break

Artigo recebido em 30.01.2014. Pareceres emitidos em 11.03.2014 e 31.03.2014.

Artigo aceito para publicação em 07.04.2014.

${ }^{1}$ Artigo produzido como fruto dos estudos e discussões realizados no Grupo de Pesquisa "Direito, Sociedade e Cultura", do Programa de Pós-Graduação Stricto Sensu em Direitos e Garantias Fundamentais da FDV (Faculdade de Direito de Vitória - ES).

${ }^{2}$ Mestre e Doutor em Direito pela Universidade do Vale do Rio do Sinos (São Leopoldo/RS). Professor do Programa de Pós-Graduação Stricto Sensu em Direitos e Garantias Fundamentais da FDV (Faculdade de Direito de Vitória - Vitória/ES). Advogado Criminalista. thiagofabres@hotmail.com

${ }^{3}$ Mestrando em Direitos e Garantias Fundamentais pela FDV (Faculdade de Direito de Vitória Vitória/ES). Professor de Direito Penal da FDV e da Escola do Ministério Público do Espírito Santo (Vitória/ES). Advogado Criminalista. idjorio@gmail.com 
with the criminogenic alienation that prevents us from recognizing the offender as one of us, i.e., as a living human being.

KEYWORDS: Penal System; Humanization; Recognition; Reification; Vengeance; Sacrifice.

SUMÁRIO: Introdução; 1. A Pena como Vingança Violenta; 2. A Coisificação do Indivíduo no Sistema Penal; 3. Compreendendo o Papel do Acusado no Sistema Penal: o reconhecimento do réu como um semelhante; Considerações Finais; Referências Bibliográficas.

SUMMARY: Introduction; 1 . The Criminal Penalty as a Violent Vengeance; 2 . The Reification of the Individual by the Penal System; 3. Understanding the Role Played by the Defendant in the Penal System: the recognition of the accused as one of us; Final Thoughts; References.

\section{INTRODUÇÃO}

Nossa Constituição é um documento riquíssimo em direitos e garantias fundamentais. São inúmeras conquistas emancipatórias individuais, sociais e metaindividuais juridicamente postas ao dispor dos brasileiros. Tão simples quanto constatar a pluralidade de valores garantistas que informam o texto constitucional é a percepção de que muitos deles não deixaram o papel ainda. A grande confiança depositada na Constituição como força normativa modificadora da realidade (conforme Paulo Roberto dos Santos Corval ${ }^{4}$, na "normatividade autônoma da Constituição") se iguala à profunda decepção causada pela visão de um mundo que conserva muitas das mesmas características do sistema anterior. As promessas não cumpridas podem acabar sendo causa de um crescente descrédito e de uma irracional vontade perene de alterar o texto constitucional. Como diz Menelick de Carvalho Netto ${ }^{5}$, o chamado "sentimento constitucional" (Pablo Lucas Verdú) "é aniquilado não só pela continuidade e prevalência das práticas constitucionais típicas da ordem autocrática anterior, mas igualmente pela tentativa recorrente de alteração formal da Constituição". Estranhamente, a falta de fé na Constituição acaba sendo um reforço para a crença na sua "normatividade autônoma", já que se pensa que a reforma textual, por si só, seja capaz resolver todos os problemas jurídicos, políticos, econômicos e sociais do nosso país.

Não seria nada sensato negar o grande salto evolutivo que experimentamos desde a Constituição de 1988. Afinal, devemos, sempre, valorizar nossas conquistas, e as dos últimos vinte e cinco anos não foram poucas, nem pequenas. Mas daí a nos contentar e acomodar há um abismo de distância. Nosso papel é, destarte, o de buscar a implementação de todas as liberdades e garantias que nos propusemos a consagrar constitucionalmente. E uma excelente ideia é começar a fazê-lo a partir das mais básicas.

\footnotetext{
${ }^{4}$ CORVAL, Paulo Roberto dos Santos. Teoria Constitucional e Exceção Permanente: uma categoria para a Teoria Constitucional no século XXI. Curitiba: Juruá, 2009.

CARVALHO NETTO, Menelick de. Requisitos Pragmáticos da Interpretação Jurídica sob o Paradigma do Estado Democrático de Direito. Belo Horizonte: Mandamentos, 2000. Revista de Direito Comparado, v. 3, p. 473.
} 
A vivência em um mundo prático que anda em descompasso com muitos dos pontos principais do nosso grande projeto constitucional talvez seja a causa de uma naturalização do descumprimento dos comandos da Constituição e, por consequência, da maior parte de nosso arcabouço legal infraconstitucional. Especialmente se direcionarmos a análise para o sistema penal, veremos que há uma série de absurdos que já tomamos como irresolúveis e decidimos acatar. Para dizer do modo mais claro possível, em vez de interpretarmos o mundo com a consciência de que "as coisas estão" assim, acabamos internalizando que "elas são assim". A diferença, colossal, reside na pessimista noção de uma pretensa imutabilidade.

Se as consequências da naturalização do descumprimento das garantias constitucionais e infraconstitucionais são sinistras para o sistema, em si, quão nefastas não devem ser para o indivíduo, isto é, para o titular das promessas não cumpridas? E se considerarmos, ainda, que ele esteja às voltas com as agruras de um sistema penal apocalíptico?

Vivemos uma época em que, felizmente ${ }^{6}$, tomamos como ponto de partida, para quase todo tipo de discussão ou reflexão jurídica, o Princípio da Dignidade da Pessoa Humana. Disso, todos sabemos que decorrem muitos direitos. Precisamos, porém (para parafrasear Dworkin) levar esses direitos a sério. A esta altura, não levar direitos tão básicos a sério é não enxergar no humano a dignidade que ele merece. Ou pior: é não divisar no homem o humano.

Negar ao indivíduo sua condição humana é coisificá-lo. É demovê-lo do posto de ser racional, livre e digno para tratá-lo como objeto do sistema penal. Eis um paradoxo: o homem é humano até que ingresse no sistema penal. Ali, transforma-se coisa. Mas, ao fim de um período de expiação de sua culpa, esperamos que se torne homem melhor (romance da ressocialização). Esse processo "homem-coisa-homem", além de não fazer sentido absolutamente nenhum, representa a mais pérfida das formas de violência: a que é meticulosamente planejada e executada.

Definitivamente, não é novidade que os rigores da lei penal são sentidos muito mais vividamente pelos desfavorecidos. A seletividade do Direito Penal se manifesta aos berros, em todas as etapas de criminalização. Na construção dos tipos e na cominação das penas, inegavelmente. Na condução do processo, sem dúvidas. E na execução da sanção, especialmente. Negar esta realidade é retomar a crença infantil, que todos já tivemos, de que ao cobrir nossos próprios olhos, ficamos invisíveis aos olhos dos outros.

\footnotetext{
${ }^{6}$ Havemos de dizer felizmente porque esse é um excelente paradigma para se adotar. É claro que precisamos desenvolver critérios mais precisos e responsáveis para o manuseio da principiologia, sob pena de a banalizarmos e cairmos naquilo que á se apelidou de "oba-oba constitucional" (SARMENTO, Daniel. O Neoconstitucionalismo no Brasil: Riscos e Possibilidades. IN: Neoconstitucionalismo(s). Coord. QUARESMA, Regina et al. Rio de Janeiro: Forense, 2009, p. 267-302). Mas nortear todas as nossas ações e debates a partir de um valor tão relevante é algo indubitavelmente positivo.
} 
Pretendemos, porém, ir um pouco mais adiante. Sem deixar de reconhecer as suavizações porventura existentes em decorrência de uma especial "consideração" para com alguns acusados (coincidentemente, em sua maioria, detentores de fatores de poder, como dinheiro ou prestígio político), cremos que a própria ocupação do posto de réu em um processo criminal, isoladamente analisada, já será causa da coisificação do indivíduo. Inicialmente, independentemente de condição financeira ou posição social ${ }^{7}$, o réu é uma coisa do sistema penal. E pior: uma coisa que se tem tornado insignificante.

Após figurar por décadas nas páginas dos livros de Direito Penal e Processual Penal, os princípios começam a receber algum prestígio por meio da aplicação prática. Uma aplicação demasiadamente tímida, receosa, conservadora a ponto de até desvirtuar-lhes a essência para um uso "menos revolucionário". É o que ocorre, por exemplo, com o Princípio da Insignificância, que tem caráter exclusivamente objetivo e deve ser aplicado sempre que a lesão ao bem jurídico for considerada desprezível, mas que vem tendo sua incidência promiscuamente condicionada a fatores como a primariedade do agente. O único Princípio da Insignificância que tem ampla e irrestrita aplicação no sistema penal brasileiro é o da insignificância do réu, infelizmente.

Para que se mude o quadro, isto é, para que passemos a respeitar o indivíduo que sofre o sistema penal, é necessário, de início, enxergar este último como uma forma de vingança violenta. Nesta parte, havemos de nos socorrer do brilhantismo de René Girard, que tão bem ilustra a geração da violência pela violência e o seu uso como um sacrifício ritual. Não menos importante, em seguida, é dimensionar o problema com o qual nos deparamos, a partir de uma breve ilustração do que seria a coisificação do homem pelo sistema penal, desde a fase investigatória até a execução da pena. Daqui em diante, seremos ajudados por Jean-Marie Müller, que também se ocupou do estudo da violência, mas sob um enfoque bastante diferente (ao que aqui nos interessa, sua eclosão e seus impactos sobre o homem). Suas lições nos serão de imensa utilidade quando abordarmos a última e mais importante das etapas desse processo de humanização do sistema prisional: o reconhecimento do acusado como um semelhante.

\section{A PENA COMO VINGANÇA VIOLENTA}

Não raramente lemos e ouvimos autoridades e especialistas se pronunciarem sobre métodos e estratégias para "eliminar a violência". O discurso, embora risível para os que detêm a óbvia noção de que a violência é ineliminável do seio das sociedades, costuma soar como verdadeiro afago para os cidadãos mais aterrorizados. Mas a verdade é que a violência é ínsita às sociedades, e permeará não apenas as relações intersubjetivas, mas, de

\footnotetext{
${ }^{7}$ Para não ficarmos insensíveis à infame realidade de disparidade de tratamentos em função de elementos econômicos e políticos, pensamos uma fórmula. A coisificação se aplica a qualquer réu. Se o réu for desfavorecido, basta elevá-la à décima potência para uma quantificação mais realista.
} 
igual modo, as respostas que as sociedades queiram dar às diversas violências que afligirem seus membros.

Com base na magistral obra de René Girard, podemos juntar as diversas peças que nos conduzem à sólida convicção de que o sistema penal é uma forma institucionalizada e ritualizada de vingança violenta.

Girard $^{8}$, o mais proficiente antropólogo da violência, constatou que "Não há, no sistema penal, nenhum princípio de justiça realmente diferente do princípio de vingança". O autor parte de uma interessante análise dos elementos da violência e do sacrifício. Do mesmo modo que o sacrifício (antropologicamente analisando, em especial, o religioso) representa uma violência, toda violência pode ser interpretada como uma forma de sacrifício. ${ }^{9}$ Girard nos fornece uma das mais inteligentes explicações para o famoso brocardo "violência gera violência". Conta que a violência jamais pode ficar sem resposta, sob pena de deflagrar um processo cíclico e interminável de desordens e reações igualmente violentas. "Caso ela não seja saciada, ela continua a se acumular até transbordar, espalhando-se em torno com os mais desastrosos efeitos."

A resposta dada à violência representa, sempre, uma vingança, que para mostrar-se suficiente e situar-se à altura daquela, envolve o derramamento de sangue. "Por que, em qualquer lugar onde grassa, a vingança do sangue constitui uma ameaça intolerável? Face ao sangue derramado, a única vingança satisfatória é o derramamento do sangue do criminoso. Não há diferença nítida entre o ato que a vingança pune e a própria vingança. Ela é concebida como uma represália, e cada represália invoca uma outra. [...] A vingança constitui portanto um processo infinito, interminável. Quando a violência surge em um ponto qualquer da comunidade, tende a se alastrar e a ganhar a totalidade do corpo social, ameaçando desencadear uma verdadeira reação em cadeia, com consequências rapidamente fatais em uma sociedade de dimensões reduzidas. A multiplicação das represálias coloca em jogo a própria existência da sociedade. Por este motivo, onde quer que se encontre, a violência é estritamente proibida." ${ }^{11}$

O papel do sacrifício é o de substituir a vingança, canalizando-a para uma "boa" direção ${ }^{12}$ (uma direção que não permita a represália posterior, isto é, que encerre a cadeia). Como o próprio sacrifício é uma violência, é preciso distingui-lo da mera vingança para que produza os efeitos desejados, em vez de apenas fazer multiplicar as reações violentas. Para isso, instituiu-se o ritual.

\footnotetext{
${ }^{8}$ GIRARD, René. A Violência e o Sagrado. Trad. Martha Conceição Gambini. 2. ed., São Paulo: Paz e Terra, 1998, p. 28.

${ }^{9}$ Idem, ibidem, p. 11-12.

${ }^{10}$ Idem, ibidem, p. 22.

${ }^{11}$ GIRARD, René. A Violência e o Sagrado. Trad. Martha Conceição Gambini. 2. ed., São Paulo: Paz e Terra, 1998, p. 27.

${ }^{12}$ Idem, ibidem, p. 22.
} 
O sacrifício ritual é uma violência procedimentalizada, solenizada, que serve como forma de apaziguamento.

Nos primórdios, esse apaziguamento situava, em uma das extremidades, a figura do divino. "Acredita-se que um deus reclama as vítimas: em princípio, somente ele se deleita com a fumaça dos holocaustos, vem dele a exigência da carne amontoada sobre os altares. É para apaziguar sua cólera que os sacrifícios são multiplicados". ${ }^{13}$ A partir de uma certa altura, é a sociedade que passa a exigir o sacrifício: "A vítima não substitui tal ou tal indivíduo particularmente ameaçado e não é oferecida a tal ou tal indivíduo particularmente sanguinário. Ela simultaneamente substitui e é oferecida a todos os membros da sociedade, por todos os membros da sociedade. É a comunidade inteira que o sacrifício protege de sua própria violência [...]."14

Já vimos que o desejado efeito "pacificador" somente poderia ser alcançado pelo respeito das regras rituais, pois são justamente elas os fatores de distinção em relação à vingança comum (que em vez de pôr um fim às reações violentas, suscita uma cadeia interminável de represálias). Girard observa que, nas sociedades mais primitivas, era mais difícil estabelecer regras ritualísticas hábeis a separar com segurança a "boa" e a "má" vingança. Mas isso poderia se operar com maior facilidade a partir da institucionalização da resposta pelo Poder Judiciário. Ele nota que "as decisões da autoridade judiciária afirmam-se sempre como a última palavra da vingança". ${ }^{15} \mathrm{O}$ sistema judiciário não tem por objetivo suprimir a violência ou mesmo mediá-la. Ele representa, na verdade, uma forma de racionalização da vingança, para limitá-la e aplicá-la conforme seus interesses. ${ }^{16}$

Por mais que se revista de camuflagens e intente transmitir uma ideia de pureza, o sacrifício ritualístico não consegue deixar de ser uma forma de vingança violenta. "Os homens não conseguem penetrar no segredo desta dualidade. Eles precisam distinguir entre a boa e a má violência; desejam repetir incessantemente a primeira para eliminar a segunda". ${ }^{17} \mathrm{~A}$ repetição da resposta à violência por meio do sacrifício ritualístico tende a gerar uma crise: "O sacrifício perde então seu caráter de violência santa, para se 'misturar' à violência impura, tornando-se seu cúmplice escandaloso, seu reflexo ou até mesmo uma espécie de 'detonador'". ${ }^{18}$

Essas considerações de Girard nos permitem fazer uma firme associação entre a crise do sacrifício ritualístico e pretensamente apaziguador, e a crise do sistema penal. Este último, instituído como substituto da vingança de sangue, vem se apresentando como uma forma de violência tão bestial e

\footnotetext{
${ }^{13}$ Idem, ibidem, p. 18.

${ }^{14}$ Idem, ibidem, p. 19.

${ }^{15}$ GIRARD, René. A Violência e o Sagrado. Trad. Martha Conceição Gambini. 2. ed., São Paulo: Paz e Terra, 1998, p. 28.

${ }^{16}$ Idem, ibidem, p. 35.

${ }^{17}$ Idem, ibidem, p. 53.

${ }^{18}$ Idem, ibidem, p. 56.
} 
desordenada que em nada difere da violência que visa conter. É - para aproveitar a fala de Girard - um cúmplice escandaloso da violência. É reflexo da violência social (exclusão) e o detonador de tantas outras violências (violências intra cárcere e post cárcere). Mais cedo ou mais tarde, "a violência desencadeia-se contra os seres que o sacrifício deveria ter protegido". ${ }^{19}$

Nada distinta da crise do sistema penal, "A crise sacrificial, ou seja, a perda do sacrifício, é a perda da diferença entre a violência impura e a violência purificadora. Quando se perde esta diferença, não há mais purificação possível e a violência impura, contagiosa, ou seja, recíproca, alastra-se pela comunidade". 20

Quando não respeita as regras do ritual (que, ainda dentro da analogia com o sistema jurídico, poderiam ser representadas pelo devido processo legal e pelas garantias fundamentais do indivíduo, antes, durante e após o processo), ou quando é banalizado, "o sacrifício não é mais capaz de cumprir sua tarefa; ele aumenta a torrente de violência impura que não consegue mais canalizar". ${ }^{21}$

Mudamos os nomes. Não chamamos de sacrifício, mas de condenação; não chamamos de vingança, mas de pena; não usamos mais ritual, mas processo.

Não conhecemos nenhuma sociedade do mundo contemporâneo que possa efetivamente abolir seu sistema penal e abrir mão, por completo, das penas. A verdade é que precisamos delas. Parece que se dispuséssemos de outros meios suficientemente eficazes para atingir os mesmos resultados que a pena, eles seriam preferíveis. Esse não é apenas o discurso do Direito Penal Mínimo ou a repetição Princípio da Intervenção Mínima, que posiciona o Direito Penal como ultima ratio. É uma lógica imperiosa - desde que não se trate de puro sadismo - tentar usar os métodos menos dolorosos possíveis à luz dos fins almejados.

Esse é um pensamento que até costumamos adotar quando prestigiamos o Princípio da Proporcionalidade das Penas. Especialmente se considerarmos a previsão das penas restritivas de direitos e das multas como sanções penais cabíveis para as infrações que não sejam consideradas graves. Para estas últimas, porém, não conseguimos ainda um substituto à altura para o encarceramento. ${ }^{22}$ Queremos, aqui, apenas deixar claro que as penas de prisão são necessárias, mas que nossa dependência não as transforma em algo bom.

\footnotetext{
${ }^{19}$ Idem, ibidem, p. 58.

${ }^{20}$ GIRARD, René. A Violência e o Sagrado. Trad. Martha Conceição Gambini. 2. ed., São Paulo: Paz e Terra, 1998, p. 67.

${ }^{21}$ Idem, ibidem, p. 57.

22 Duas observações. Primeiro, abandonamos desde logo a possibilidade de penas de morte, banimento, mutilação ou outras especialmente cruéis (já que a pena de prisão, nas condições em que a executamos, também é cruel). Em segundo lugar, as penas de prisão estão, obviamente, igualmente sujeitas ao Princípio da Proporcionalidade das Penas, embora nosso legislador aparentemente haja desconsiderado sua existência ao cominar as sanções in abstrato (vide, por exemplo, as penas previstas para os crimes patrimoniais, em geral).
} 
A prisão é um mal necessário. ${ }^{23}$ Se a necessidade salta à vista, com sua consideração como um mal não pode ocorrer diversamente. Nas palavras de Mir Puig ${ }^{24}$,"Nadie puede negar que la pena es un mal que se impone como consecuencia de un delito. La pena es, sin duda, un castigo. Aquí no valen eufemismos [...]".

Temos que partir de uma premissa que não é nada agradável: a pena de prisão, sanção penal por excelência da maior parte dos sistemas penais contemporâneos, tem por fim causar sofrimento ao condenado.

Essa constatação é tão inquietante porque nos faz aproximar a pena da tortura, e nós mesmos, dos carrascos. Precisamos de algo para racionalizar a pena, isto é, para torná-la racionalmente aceitável. Para isso desenvolvemos diversas teorias sobre os fins ou funções da pena.

À pena, no discurso acadêmico, atribuem-se muitas funções. Independentemente da opção por qualquer das várias correntes, alguns dados serão sempre certos: 1 ) a pena é dada como resposta a uma infração; 2) a pena é um meio, nunca um fim.

O primeiro dos dados é bastante seguro. Somente admitimos a pena como a resposta do Estado a um comportamento que, após o devido processo legal, tenha sido considerado criminoso (ou, nos termos da melhor doutrina da teoria do delito, um fato formal e materialmente típico, ilícito e culpável). E essa resposta, em nossas mentes, tem um fim, um propósito. A pena é aplicada como meio para se obter algo. Se esse "algo" (fim) é apenas a retribuição do mal causado pelo crime; se é a intimidação da sociedade; se é a sedimentação de valores socialmente relevantes; se é a negação da negação da lei ou a reafirmação do sistema; se é a "(res)socialização" do condenado ou meramente a sua exclusão do corpo social; não importa. A pena, em si, não passa de um meio.

Para que a pena alcance os resultados que dela esperamos, ela precisa ostentar forte caráter aflitivo. Ela deve ser levada a sério e, para isso, é preciso que seja consideravelmente dolorosa. Pensamos a pena, especialmente a pena de prisão, como uma forma de desestimular o crime, e isso somente será possível se a pena for temida. E para que seja efetivamente temida, deve ser capaz de causar grande sofrimento. O medo da pena é o medo do sofrimento. Hoje, nos esforçamos por dissimular essa verdade tão gritante. Mas ela é ainda incontestável. Condenamos o passado por suas barbáries, mas será que há diferença essencial entre o esquartejamento por tração animal em praça pública, relatado por Foucault como intróito de seu Vigiar e Punir,

\footnotetext{
${ }^{23}$ Foucault, que denunciou magistralmente a tragédia das penas, acabou por ter que reconhecê-las como "a detestável solução, de que não podemos abrir mão". IN: FOUCAULT, Michel. Vigiar e Punir. Trad. de Raquel Ramalhete. 20. ed., Petrópolis: Vozes, 1999, p. 196.

${ }^{24}$ MIR PUIG, Santiago. Estado, Pena y Delito. Montevidéu: Editorial B de F, 2006, p. 41. "Ninguém pode negar que a pena é um mal que se impõe como consequência de um delito. A pena é, sem dúvida, um castigo. Aqui, não valem eufemismos [...]". Tradução nossa.
} 
e a manutenção da máquina de tortura que é o sistema carcerário? Ambos não são extremamente dolorosos e publicamente expostos como um horrendo espetáculo de violência?

Não há dúvida: para alcançar seus fins, a pena precisa infligir dor. Essa conclusão nos autoriza, inclusive, a trabalhar com a cisão entre fim imediato e fim mediato da pena. O fim formal e classicamente estabelecido para a pena (prevenção geral, prevenção especial, etc.) somente se pode alcançar após a consecução do fim imediato: a causação da dor. É após causar a dor de um condenado e depois de exibi-la aos outros cidadãos que se estabelece seu temor. E o próprio condenado deve "sofrer o suficiente para não voltar a delinquir" (ressocialização ou traumatização). Como ressalta Mir Puig ${ }^{25}$, "no ha de pretender ocultar el carácter aflictivo y negativo de la pena para el penado. Ha de empezarse por evitar el eufemismo y reconocer que nos es el bien del delincuente, sino la necesidad de protección social, lo que justifica la intervención penal".

É evidente, no entanto, que há um compromisso indissolúvel no sentido de estabelecer limites, assim como de zelar para que eles sejam respeitados. É por isso que devemos não apenas proclamar constitucionalmente, mas fazer uso prático dos Princípios da Limitação, da Proporcionalidade, da Individualização e da Intranscendência das Penas. Se a pena será sempre uma terrível aflição, devemos conter seus danos ao máximo; se será inevitavelmente uma violência, deve ser a violência mais comedida possível. Se, enfim, representa sempre uma crueldade, que seja a menor crueldade possível.

Essa é a visão realista que devemos ter para compreender que, só de estar preso, o condenado sofrerá. Isso já é uma agressão. Pergunta Jean Marie-Müller" ${ }^{26}$ : "não é a prisão ainda considerada como uma penitenciária, isto é, no rigor do termo, como um lugar onde se faz penitência?" Passar anos sem ser dono de sua liberdade, ainda que estabeleçamos condições mais dignas de permanência (celas individuais limpas; refeição adequada; espaço para exercícios; acesso ao trabalho e à cultura; direito a visitas periódicas), não deixa de ser um grande sofrimento. A vida extra-muros segue incontrolável. Casamentos se acabam, filhos crescem distantes, pais falecem, trabalhos se perdem, perspectivas futuras se estreitam. A solidão do cárcere é uma tragédia. Mas o distanciamento de tudo e de todos que já fizeram e fazem parte da vida do condenado não é menos dolorido. Esse é o sofrimento da pena de prisão, ou mesmo da submissão a um processo criminal. Fere o espírito, atormenta a alma. Já não é mal o suficiente? Com esse mal, se dependemos da pena de prisão, temos que lidar. Mas não há justificativa absolutamente nenhuma para

\footnotetext{
${ }^{25}$ MIR PUIG, Santiago. Estado, Pena y Delito. Montevidéu: Editorial B de F, 2006, p. 75-76. "Não se deve pretender ocultar o caráter aflitivo e negativo da pena para o apenado. Deve-se começar a evitar o eufemismo e passar a reconhecer que não é o bem do delinquente, mas a necessidade de proteção social, o que justifica a intervenção penal." Tradução nossa.

${ }^{26}$ MÜLLER, Jean-Marie. O Princípio de Não-violência. Trad. Maria Fernanda Oliveira. Lisboa: Instituto Piaget, 1995, p. 132.
} 
que convivamos com as atrocidades que vicejam em nosso sistema penal. Com o tratamento desrespeitoso do réu ou o suplício monstruoso do condenado, que, bem mais que a liberdade, perde a saúde, a dignidade sexual, o autorespeito, o respeito pelos outros e, por fim, a esperança de uma vida futura.

Entender as penas como uma violência é importante para que sejamos responsáveis ao cominá-las e aplicá-las. Pode parecer uma incoerência identificar o encarceramento como uma forma de tortura, de um lado, e sustentar a sua imposição, de outro. Mas isso decorre da infeliz constatação de que elas são, como já dito, um mal necessário.

Evidentemente, "Não é possível organizar uma sociedade de direito sem definir delitos e sem estabelecer sanções. Mas ao mesmo tempo em que a sanção penal deve permitir à sociedade defender-se, ela deve permitir ao delinquente reinserir-se na sociedade. Se o delinquente perde alguns dos seus direitos na sociedade, esta não perde nenhum dos seus deveres em relação a ele". ${ }^{27}$

Ao final dessas considerações, já podemos estabelecer o grau de consciência que é minimamente desejável para uma humanização do sistema penal: quando condenamos alguém, devemos saber que vamos torturá-lo. E devemos saber, também, que quem será torturado é um semelhante.

É somente conhecendo a natureza violenta do sistema penal, e reconhecendo a natureza humana do seu destinatário, que poderemos tolerar a restrição de direitos fundamentais (do condenado) com o paradoxal propósito de salvaguardar direitos fundamentais (os bens jurídicos penalmente tutelados).

Infelizmente, é bem outra a imagem da nossa realidade. Por meio de um sistema penal putrefato, os homens "purificam-se manchando-se com outro sangue, como se alguém, entrando na lama, em lama se lavasse". ${ }^{28}$

\section{A COISIFICAÇÃO DO INDIVÍDUO NO SISTEMA PENAL}

Conta-nos Jean-Marie Müller ${ }^{29}$ que toda violência é uma forma de homicídio, isto é, tenciona a eliminação do outro. Mas o autor alerta: "Há uma outra violência, muito mais variada nos seus processos e surpreendente nos seus efeitos". Em seguida, citando Simone Weil, fala sobre a coisificação. Ela é a violência "[...] que não mata; isto é, aquela que ainda não mata. Ela vai certamente matar, ou talvez vá matar, ou fica em suspenso sobre o ser que a todo momento pode matar; de qualquer forma, transforma o homem em pedra. Do poder de transformar um homem em coisa, fazendo-o morrer, deriva um outro poder prodigioso de uma outra forma, o de fazer uma coisa de um homem que continua vivo".

\footnotetext{
${ }^{27}$ MÜLLER, Jean-Marie. O Princípio de Não-violência. Trad. Maria Fernanda Oliveira. Lisboa: Instituto Piaget, 1995, p.132.

${ }^{28}$ GIRARD, René. A Violência e o Sagrado. Trad. Martha Conceição Gambini. 2. ed., São Paulo: Paz e Terra, 1998, p. 60.

${ }^{29}$ MÜLLER, Jean-Marie. O Princípio de Não-violência. Trad. Maria Fernanda Oliveira. Lisboa: Instituto Piaget, 1995, p. 31.
} 
E o autor arremata: "Contudo, aquilo que distingue de uma coisa o homem atingido pela violência e que continua vivo é o facto de ele sofrer. Violentar é fazer sofrer e o sofrimento pode ser mais temível que a morte".

O sistema penal, já vimos, representa uma forma de violência em todas as suas etapas. Desde a fase investigatória até a execução da pena, submete o homem a um processo de coisificação, que, nas condições especialmente ofensivas e degradantes que marcam a realidade brasileira, dá-se com extraordinária eficiência.

Os exemplos que passaremos a expor não são fruto de uma perscrutação rica em minúcias. São constatações gritantes, que saltam aos olhos diuturnamente nos círculos de debates acadêmicos e nos fóruns e Tribunais do Brasil.

É bom começarmos pelo uso da palavra réu no processo penal. Mas, afinal, qual seria problema com a expressão em questão? Sem desviar nosso foco para extensas análises etimológicas, apenas lembramos ao leitor que usamos réu, para o sujeito do processo; res, para o objeto material do furto ou roubo; Direito real (de res), para o Direito das coisas. Resto, para a coisa que sobra. E rês, para a cabeça de gado (talvez o exemplo mais sugestivo e adequado à realidade do sistema penal). Talvez os mais céticos queiram interpretar essas observações como mera implicância. Mas será que essa designação é tão imprescindível? Não poderia ser substituída, em definitivo, por "acusado" ou "imputado", por exemplo?

A superlotação do sistema carcerário é uma forte prova de que o indivíduo é coisificado. O sistema prisional brasileiro é um imenso porão. Nele, colocamos coisas que não nos têm grande utilidade no dia a dia, mas que decidimos não jogar fora (no caso do sistema penal, porque não admitimos a pena de morte). Coisas velhas, defeituosas, ultrapassadas ou cujo valor não seja suficiente para que permaneçam na "parte nobre" da casa. Ali, empoeiram, se deterioram ainda mais e podem acabar esquecidas. Quando acumulamos muitas tralhas e tranqueiras, amontoamos as coisas, sem qualquer pretensão de conservação ou mesmo de utilização futura. Qualquer semelhança com um presídio superlotado não é mera coincidência. Os detentos também são amontoados e esquecidos em masmorras mofadas, sujas, fétidas, abafadas e mal iluminadas, e igualmente sem qualquer perspectiva de "conserto" ou utilidade futura.

O condenado, em um sistema falido, é coisa inútil. A afirmação ganha tom de literalidade quando paramos para pensar que a promessa do trabalho, que devia ser um dos principais cuidados do Estado, não é cumprida. $\mathrm{Na}$ maior parte dos presídios, não há trabalho para todos. O homem é um objeto imprestável. E o prejuízo não se esgota aí: sem trabalho, nunca terá direito a outras tantas promessas falaciosas. Não fará suas economias para um improvável recomeço futuro ou para ajudar sua família; não aprenderá um ofício; e não terá acesso á remição. 
Ficar sem cuidados é ficar esquecido. ${ }^{30}$ Esquecer-se de um condenado é torná-lo um objeto inanimado, uma coisa "não perecível" que pode ser engavetada por longo tempo. Todo homem é perecível! Esse é o reconhecimento mínimo que se pode esperar de alguém. Coisa não sente cheiro, não passa mal, não tem problemas emocionais e não adoece. Talvez por isso o ambiente seja tão imundo e insalubre; o atendimento médico, dentário e psicológico (onde ele existe), tão precário; e as necessidades dos exercícios e dos "banhos de sol" sejam desprezadas. Esquecer o condenado na masmorra é deixar de reconhecê-lo como vivo. É matá-lo mentalmente, então.

A Lei de Execução Penal garante ao condenado, no regime fechado, o isolamento noturno em cela individual. Cela esta que, segundo a propaganda enganosa de uma legislação que tenciona vender um produto de que não dispõe, terá pelo menos seis metros quadrados; será composta por dormitório, aparelho sanitário e lavatório; e garantirá a salubridade pela concorrência dos fatores de aeração, insolação e condicionamento térmico adequado à existência humana $^{31}$ (art. 88). A descrição deste pequeno espaço de desgraça, aos ouvidos da maioria da população carcerária, desperta a imagem de uma suntuosa suíte de hotel. Afinal, como regra, um preso somente possui uma cela toda sua quando é submetido ao regime disciplinar diferenciado. $\mathrm{E}$ ali, a história do isolamento é levada muito a sério, ultrapassando absurdamente o limite do período noturno e podendo se estender por meses. No RDD, mais uma vez negamos ao detento o dom da vida. A vida existe na intersubjetividade. Sou vivo diante de alguém, que me reconheça como tal, e com quem possa interagir. O silêncio do RDD coisifica com grande eficiência, privando o homem daquilo que o constitui como ser, que é exatamente a linguagem. Nas palavras de Jean-Marie Müller ${ }^{32}$, "ao proibir-lhe qualquer comunicação com outra pessoa e ao privá-lo de toda a responsabilidade, impomos-lhe comportamentos de regressão que tendem a desintegrar sua pessoa".

Ao falar de regime prisional, somos doutrinados a pensar na progressão. A progressão é um direito muito claramente assegurado ao condenado. Mas, se não há vagas no regime semiaberto ou aberto, permanece o detento onde se encontra, até segunda ordem ${ }^{33}$. Como ser humano digno, se cumpre período

\footnotetext{
${ }^{30}$ E lembramos, ainda, que de tempos em tempos, ganham os holofotes da mídia casos de pessoas que ficaram presas por período superior àquele constante na sentença condenatória, 0 que é um tanto pior quando ocorre durante o processo.

${ }^{31}$ No Espírito Santo, containers de metal foram adaptados para "acondicionar" um tipo de produto muito peculiar. Em vez das tradicionais mercadorias, contiveram, por um tempo, condenados para os quais não se pôde destinar uma vaga nos tradicionais presídios de concreto, já tão superlotados. Em uma região em que as altas temperaturas eventualmente beiram os quarenta graus, tem-se uma ideia da aeração e do condicionamento térmico a que se referiu a lei.

${ }^{32}$ MÜLLER, Jean-Marie. O Princípio de Não-violência. Trad. Maria Fernanda Oliveira. Lisboa: Instituto Piaget, 1995, p. 132.

${ }^{33}$ É claro que, em muitas situações, a progressão é ordenada a partir da concessão da ordem em habeas corpus. Mas precisar do habeas corpus, nesse caso, já é uma prova do esquecimento. Além disso, nem todos terão seu writ de imediato impetrado, conhecido e deferido.
} 
o exigido legalmente e não possui má conduta carcerária, tem que ser conduzido a um regime mais brando. Como coisa, pode ser mantido onde está. Coisa não sofre. Não se angustia, como ocorre com o homem, quando toma a consciência de que já deveria estar gozando de uma dose maior de liberdade.

Mas voltemos um pouco. Examinemos o momento que precedeu ao ingresso do indivíduo nesse lugar infernal. Sobram razões para que vejamos o processo penal como um procedimento identicamente coisificador. Com atenção, veremos que o indivíduo não é coisificado ao entrar no sistema prisional. Ele já entra como coisa.

Partamos do básico. Ao indivíduo foram prometidas incontáveis garantias constitucionais. Mas ao réu, que é coisa, elas não fazem falta. Coisa não sabe distinguir sistema acusatório de sistema inquisitório. Não saberia, assim, que é um absurdo condenação sem acusação, por exemplo. ${ }^{34}$

Coisa não compreende a garantia da ampla defesa e do contraditório, de modo que não percebe o quanto é esdrúxula a presença de uma fase investigatória preliminar em que o único direito que possui é o de ficar em silêncio.

Eis aqui a justificativa para que o réu seja retirado da sala de audiências quando a vítima se sente constrangida com sua presença: a vítima é pessoa; o réu é coisa. A vítima, na quase totalidade das situações, não corre nenhum risco de ser ali agredida. Mas o prejuízo emocional justifica a retirada do acusado. Este, por sua vez, pode ter sérios prejuízos para sua defesa, pois não estará ao lado de seu advogado para ouvir e comentar com o defensor as palavras da vítima. Coisa pode ser simplesmente removida.

Pensando nisso, compreendemos porque ainda se sustenta que 0 suspeito ou o réu pode ser conduzido coercitivamente à delegacia ou à sala de audiências. O homem possui o direito constitucional de permanecer em silêncio, o que faria da sua presença uma completa inutilidade. Mas não falamos de homem, e sim de coisa. Coisa se leva para cá e para lá.

Assistência do acusado por um advogado não é um luxo. Isso parece ter ficado muito claro: a defesa técnica é essencial para a ampla defesa, que é um direito fundamental do indivíduo. Mas não da coisa. Para a coisa, se ela está desassistida, basta chamar um dos muitos advogados que passam diante da porta da sala de audiências. A presença de um advogado que nunca viu a coisa, não conhece o processo e, possivelmente, não saberá o que perguntar ou requerer, é suficiente. Esse teatro ridículo, encenado com a maldosa intenção de suprir a exigência da "presença" de um advogado, coisifica não só o réu, mas também o advogado que é usado como placebo.

A síntese suprema das garantias processuais é o Princípio do Devido Processo Legal. Além dos já citados contraditório e ampla defesa, dele defluem,

\footnotetext{
${ }^{34}$ Referimo-nos, obviamente, ao posicionamento dominante segundo o qual o magistrado detém poderes para condenar mesmo diante do pedido de absolvição elaborado pelo Ministério Público.
} 
dentre outros, a paridade processual e a exigência da fundamentação das decisões judiciais. A paridade processual é algo a ser lembrado sempre que se estabelece a tensa relação entre o Ministério Público e o indivíduo acusado. Na maior parte das salas de audiência e dos Tribunais, já começamos mal: a coisa fica distante, com seu advogado, geralmente em lugar mais baixo. O representante do Ministério Público se assenta ao lado do juiz. Qualquer ser humano racional se incomodaria com os cochichos (e até risinhos) que ocorrem entre aquelas duas figuras imponentes e simbolicamente aproximadas durante a audiência. "Será que haverá imparcialidade? O julgador parece tão íntimo do acusador... Eles lá em cima, juntos e tão descontraídos... Eu aqui embaixo, nervoso e por conta própria....". A coisa não presta atenção a esses detalhes. ${ }^{35}$ A coisa nem percebe, aliás, que quando apela, um membro do Ministério Público contra-arrazoa, e outro torna a se manifestar, na instância superior, sem que a mesma oportunidade the seja oferecida... Mas as oportunidades de manifestação não devem ser iguais? E a palavra da defesa, também neste caso, não deve ser a última? E se o Procurador, em seu parecer, resolver aduzir argumentos ou acrescer fundamentos sobe os quais o réu não pôde se manifestar? É que coisa não pensa. Dizem que isso não ocorre, pois o membro do Ministério Público, nesse caso, funciona "apenas como fiscal da lei". Se a coisa pensasse saberia que não é bem assim.

Aliás, há muitas outras situações que, se o réu fosse tratado como ser humano pensante, não existiriam. A fundamentação das decisões judiciais, além de ser importante feição do devido processo legal, é prevista como indispensável condição de validade pelo art. 93, IX, da Constituição. Ainda assim, vigora o entendimento de que "o juiz não precisa se manifestar sobre cada uma das teses da defesa". Segundo este raciocínio, pode optar por rejeitá-las por atacado, reunindo-as em um "pacotão" sobre o qual se inscreve a palavra "não". Muito interessante, também, notar o quanto são frequentes decisões que fundamentam a condenação por meio da afirmativa de que "a culpa restou comprovada a partir dos elementos dos autos". Ou "as provas apontam para a responsabilidade do acusado". Ou ainda "comprovadas autoria e materialidade...". No intuito de obter algum esclarecimento, interpõem-se embargos de declaração, mas a chance de que estes sejam considerados protelatórios é imensa. Afinal, o juiz, ao fixar a pena-base, fundamentou a culpabilidade: ela é elevada "pois o fato é grave"; "porque a conduta é reprovável"; ou, o que é pior, ao custo do assassínio da Teoria do Delito de orientação welzeliana, "porque a intensidade do dolo é grande" [sic]. A conduta social também foi fundamentada: "é péssima". O mesmo se diga acerca da personalidade: "é voltada para o crime". Pior que isso tudo, talvez seja a fundamentação da consideração negativa dos motivos do crime para fim de fixação da pena-base em valor mais elevado: "a ganância", nos crimes

\footnotetext{
${ }^{35}$ Esses são "detalhes" que, são não traduzem nenhuma tendência ou malícia, podem (devem) ser suprimidos. Juiz e promotor não perdem nada. E a isonomia só tem a ganhar.
} 
patrimoniais; "o ânimo de lucro fácil", no tráfico de drogas; "a luxúria", nos crimes sexuais. Todos esses "argumentos", se fossem dirigidos a um ser pensante, que tem o direito de compreender por que foi condenado, e por que sua pena foi estabelecida naquele patamar, soariam ridículos. Mas não são. Dirigem-se ao réu. À res (ou à rês).

Para complicar um pouco mais a vida da res, ela pode ser condenada por crimes sem vítima e independentemente da comprovação da criação de um perigo a partir de sua conduta (delitos de perigo abstrato); por crimes que não lesam concretamente bens jurídicos (atos sexuais consentidos por pessoa de treze anos com conhecida experiência sexual prévia); e por infrações sem gravidade (furtos de bagatela, ainda que seja realizada a reparação do prejuízo antes do recebimento da denúncia, se tiverem sido cometidos durante a noite, no interior de residências, com chave falsa ou em concurso de pessoas, pois os Tribunais têm se esforçado por inserir diversos requisitos subjetivos no âmago de um princípio que é puramente objetivo). Por fim, quando seu advogado enfrenta o tipo penal, desconstruindo cada uma das elementares típicas, é surpreendido com odioso aforismo: "o réu não se defende das imputações, mas dos fatos". A imputação é irrelevante, não é mesmo? A pena apenas dobra, triplica ou quadriplica... Que alguém nos explique, por favor: como sustentar a tese da atipicidade da conduta sem fazer referências diretas à imputação? É por isso que tudo pode sempre mudar de última hora. Sou processado por um crime mais leve, mas o juiz, ao final, pode reclassificar a infração, por conta própria, sem dar-me direito à palavra (pois me defendi dos fatos!). Isso comprova de vez que nosso sistema não é "acusatório misto", mas "inquisitorial misto". Mas, para a coisa, qualquer coisa serve.

A partir desses poucos exemplos (um estudo específico nesse sentido certamente preencheria muitas dezenas de páginas), constatamos, com grande desgosto, que o réu não apenas é tratado como coisa pelo sistema penal, mas como uma coisa insignificante. Pois, como bons seres materialistas, consumistas ou capitalistas que somos, tendemos a dar às coisas algum valor. Dispensamos às coisas tratamento condizente com os respectivos valores que lhes atribuímos. Protegemos, conservamos e cuidamos. Se não tratamos o réu deste modo, é porque ele não possui valor nenhum.

\section{COMPREENDENDO O PAPEL DO ACUSADO NO SISTEMA PENAL: O RECONHECIMENTO DO RÉU COMO UM SEMELHANTE}

Qualquer manual de Direito Processual Penal, do mais chinfrim ao mais elaborado, provavelmente classificará o réu como um sujeito do processo. O que isso nos diz? Absolutamente nada. Já começamos mal, pois a classificação é o primeiro passo para a entificação de um ser. Aliás, classificar nem mesmo se confunde com conceituar. Classificar é apor um rótulo e inserir em uma gaveta ou prateleira. Mas o que é que estamos classificando, afinal? Não precisamos compreender o objeto para que o possamos classificar adequadamente? 
Em nada nos ajudam conceitos rasos como "réu é aquele que ocupa o polo passivo da ação penal"; "é aquele sobre quem recai a imputação de uma infração penal"; "é aquele que resiste à pretensão acusatória"; etc. Para que possamos efetivamente respeitar o acusado, devemos compreendê-lo. Precisamos compreender o papel do réu no processo penal e o papel do processo penal para o réu.

Um primeiro passo para que se estabeleça uma relação mais respeitosa com o acusado pode se dar a partir da resposta à pergunta "qual a importância do réu para o processo penal?". Em uma palavra, a resposta mais adequada seria vital. A importância do réu para o processo é literalmente vital, pois sem réu, não há processo. Pode-se conceber processo sem um juiz (tribos e clãs germânicos já fizeram prova disso); pode-se ter um processo sem a figura específica do acusador (no modelo inquisitorial, o juiz acumula as duas funções); até "sem vítima" estamos acostumados a ver processos (nos crimes de perigo abstrato, por exemplo); mas sem um acusado, nunca existirá processo propriamente dito. O acusado não é uma parte no ou do processo, apenas. Ele é simplesmente o motivo pelo qual se concebeu o próprio processo penal. Intuitivamente se poderia pensar que o processo penal faz nascer o réu, mas é exatamente o contrário que se verifica. O processo está a serviço do réu. É uma criação do homem para o homem. Um emaranhado de regras e princípios que têm por escopo resguardá-lo de seus próprios excessos.

E qual a importância do processo penal para o réu? Também não é pequena. Um processo penal, especialmente se envolver a possibilidade concreta de aplicação de pena de prisão, decidirá a vida do acusado. Nesses casos, também é possível dizer que a importância do processo para o réu é vital.

$\mathrm{Na}$ penumbra da triste realidade de muitos fóruns e Tribunais, o mais comum, é que o réu seja considerado como objeto do processo. Já seria avanço se se levasse a sério a noção de que o réu é, pelo menos, na linha das mais básicas lições de Direito Processual Penal, um sujeito do processo. ${ }^{36}$ Sim, porque o sujeito é vivo. É de carne e osso. Sente.

Convidamos o leitor a uma sucinta reflexão acerca - como se costuma dizer nas obras cinematográficas - de uma "história baseada em fatos reais". Certo advogado criminalista, em início de carreira, aguardava com seu trêmulo cliente (um rapaz de vinte e poucos anos, cuja vida era quase só trabalho e estudo, e que nunca conhecera os interiores de fóruns ou delegacias) a

\footnotetext{
${ }^{36}$ Lembrando Mir Puig, "Importa huir del tratamiento del acusado como mero objeto a adaptar, y propugnar, en cambio, que se parta de su consideración como sujeto. Sólo así se respeta la dignidad que debe reconocerle un Estado no sólo social, sino también democrático". MIR PUIG, Santiago. Estado, Pena y Delito. Montevidéu: Editorial B de F, 2006, p. 74. "Importa fugir do tratamento do réu como mero objeto a se adaptar, e propugnar, em vez disso, que se parta de sua consideração somo sujeito. Só assim se respeita a dignidade que the deve reconhecer um Estado não apenas social, mas também democrático." Tradução nossa.
} 
chegada do promotor de justiça à sala de audiências. A determinada altura, a juíza, que ali já se encontrava, rompeu o silêncio com uma pergunta dirigida ao réu: "Você está nervoso? Está com medo de alguma coisa?" Evidentemente, o arremate não poderia ser outro: "Quem não deve, não teme". O defensor, estupefato e pego de surpresa, não conseguiu pensar em uma resposta à altura. Apenas observou: "É porque ele está sentado aqui, no banco dos réus. Qualquer um que se assentar aqui ficará nervoso". A atitude de escárnio daquela autoridade até merecia resposta mais ácida. Mas, se continuar a agir assim, oportunidades não faltarão para que receba a reprimenda adequada. O que nos importa, por agora, é entender o porquê de a magistrada haver agido assim com o réu. Não parece ser difícil chegar a uma razão plausível. Se ela nunca o havia visto antes, certamente não seria nada pessoal. Só pode ser fruto de uma pré-compreensão segundo a qual um réu não tem os mesmos sentimentos que uma pessoa qualquer. Dizendo o mesmo de outro modo, a atitude exprime claramente a falta de reconhecimento do réu como pessoa (como um semelhante).

Claro que essa prática não foi inaugurada pela juíza. E, obviamente, não é local, e nem recente. Origina-se a partir da disseminação e gradual sedimentação da ideia de separação entre os puros e os impuros (sociedades primitivas); os justos e os ímpios (judaísmo); os salvos e os perdidos (cristianismo); os corretos e os incorretos (ética racionalista); e, mais proximamente, no âmbito jurídico, os cidadãos e os inimigos (estrangeiros, em Schmitt; transgressores, em Jakobs). Para não me identificar com o impuro, ímpio, perdido, incorreto ou inimigo, devo demonizá-lo, isto é, recusar-lhe sua condição humana. Ora, se ele, o transgressor, é humano como sou, somos semelhantes. Reconhecer essa semelhança significa reconhecer a própria suscetibilidade aos mesmos erros, o que é extremamente desagradável. É por isso que os criminosos nunca somos nós, mas sempre eles, os outros. O crime não é uma obra nossa; não temos sobre ele nenhuma responsabilidade. Continuamos puros, justos, salvos, corretos e cidadãos. Este é um pensamento que decidimos chamar de alienação criminogênica.

Esse ilusório distanciamento do indivíduo que cometeu um crime retoma o que de pior se pode extrair da Scuola Positiva: a imagem do "homem delinquente". Como lembra Gabriel Ignacio Anitua ${ }^{37}$, "Essa denominação seria a de um ente diferenciado, como outra 'raça' em tudo diferente da dos seres humanos normais."

Ver o réu como pessoa é uma atitude definitiva de impactos magnânimos. Afinal, "o encontro com o outro homem faz-me descobrir o seu rosto, 'pois o rosto é a própria identidade de um ser"'. ${ }^{38}$

\footnotetext{
${ }^{37}$ ANITUA, Gabriel Ignacio. Histórias dos Pensamentos Criminológicos. Trad. Sérgio Lamarão. Rio de Janeiro: Revan, 2008, p. 297.

${ }^{38}$ MÜLLER, Jean-Marie. O Princípio de Não-violência. Trad. Maria Fernanda Oliveira. Lisboa: Instituto Piaget, 1995, p. 69.
} 
Para um julgador, reconhecer o acusado como semelhante é algo tão útil quanto incômodo. Em primeiro lugar, é útil, porque eleva as chances de um julgamento mais responsável e mais justo. É que "a descoberta do rosto do outro homem na sua vulnerabilidade e na sua transcendência faz-me tomar consciência simultaneamente da possibilidade e da impossibilidade do homicídio; esta tomada de consciência é a afirmação da minha consciência moral". ${ }^{39}$

De outro lado, é um incômodo, porque julgar um semelhante é uma tarefa cujo peso é angustiante. Se realmente vemos a semelhança, isto é, se realmente nos enxergamos no outro, estamos, de certa forma, a julgar-nos a nós mesmos. Que doloroso exame de consciência isso exige!

Enxergar a humanidade no outro é, de certa forma, reconhecer a fragilidade e a falibilidade que todos temos. É ser, na melhor acepção da palavra, compreensivo, isto é, participante do mundo de sentidos e significados do qual aquela pessoa faz parte. Descemos do plano etéreo, nos inteiramos da mortalidade e passamos a ter medos em comum. Julgar o bandido, o criminoso, o meliante ou mesmo o réu é bem mais simples que julgar um ser humano digno de uma dose de respeito imanente e ineliminável. De alguma forma, a partir daqui, é a humanidade que se assenta no banco dos réus.

Quando pouco, o reconhecimento do outro deve refrear o ímpeto de vingança, o desejo de retribuir e de "fazer uma justiça pessoal" a partir de um castigo exemplar. Reconhecer é importante porque significa desarmar-se: "O olhar do outro, pela resistência ao homicídio que exprime, paralisa meu poder e desarma minha vontade. Assim, 'a ideia de infinito, longe de violar o espírito, condiciona a própria não-violência, isto é, instaura a ética"”. ${ }^{40}$

A aceitação de que - por pior que tenha sido o crime cometido, ou por mais reprovável que julguemos a conduta - nada será suficiente para desfazer a humanidade do outro, clarifica a dimensão da tragédia que é uma condenação criminal. Especialmente se ela envolver a incursão no inferno, isto é, a passagem pelas masmorras do nosso sistema carcerário. Esse tipo de decisão condenatória é uma bomba para o passado, o presente e o futuro. Retira-se tudo o que o indivíduo tem; limita-se drasticamente tudo o que ele poderá vir a ter; e elimina-se qualquer passado respeitável.

Uma decisão condenatória nunca deveria ser objeto de celebração. Nem mesmo se referir-se ao crime mais brutal ou ao criminoso mais temido. Afinal, ela representa, quase sempre, a destruição de uma vida humana. É nosso senso retributivo de justiça que dificulta muito essa percepção. Somos condicionados historicamente à lógica do "bem-feito". Assim, mesmo se chegar a nos passar pela mente a dimensão do sofrimento que será experimentado pelo condenado, não nos comoveremos, porque, no fim das contas, "ele merece".

\footnotetext{
${ }^{39}$ MÜLLER, Jean-Marie. O Princípio de Não-violência. Trad. Maria Fernanda Oliveira. Lisboa: Instituto Piaget, 1995, p. 69.

${ }^{40}$ Idem, ibidem, p. 70.
} 
Um homicídio cometido em legítima defesa, ou mesmo a morte de um inimigo pelo soldado, em estrito cumprimento do dever legal, não deve ser objeto de celebração. Ambos devem ser deplorados, pois ali extinguiram-se violentamente as vidas seres humanos. Pelas circunstâncias, é justo e correto que não se puna aquele que matou. Mas nem por isso a morte deve se transformar em algo bom, positivo, digno de louvor. ${ }^{41}$

Louvar o homicídio é desencadear um processo de banalização da violência que pode culminar com a perda de sensibilidade acerca do valor da vida do outro, isto é, da vida humana. Essa morte violenta deve suscitar pesar em quem a causa e em todos os que dela se inteirarem, porque, independentemente da palavra absolutória da Justiça, encerra um fato muito grave e extremamente negativo. Desprezá-lo é o primeiro passo para a coisificação. Quem foi destruído não era coisa, e isso jamais pode ser olvidado. Aqui, vale lembrar a crítica de Hans Welzel ${ }^{42}$ sobre a teoria dos elementos negativos do tipo. Welzel, muito mais que um brilhante doutrinador da dogmática penal, foi um filósofo notável. Com razão, afirmou que não se poderia considerar a morte de uma pessoa em legítima defesa como um fato atípico, pois isso seria o mesmo que asseverar a irrelevância jurídica da ação. Mas a morte violenta de um ser humano jamais deve ser um evento juridicamente irrelevante. "Matar um homem não é o mesmo que matar um mosquito", parece ainda nos dizer. Por isso sua opção sobre a estrutura analítica que separa a tipicidade da ilicitude: o fato de ser típica a conduta atesta a sua relevância inicial para o Direito, embora seu significado, por não ser contrário aos valores éticos dominantes na sociedade e positivados, não deva ser considerado negativo em seu conjunto, não suscitando punição.

Algo semelhante pode ser pensado sobre as condenações criminais. $O$ fato de elas serem devidas não afasta seus efeitos nefastos sobre a vida do condenado. A condenação justa não é indolor. E quem a sofre não é coisa. A ação de condenar, no mundo jurídico, não é mais do que - com a permissão do uso da expressão coloquial que habita os corredores dos fóruns - uma canetada. Mas no plano da realidade, é o sepultamento de um indivíduo vivo. Não pode ser algo positivo, em si; mas, se é necessária a condenação, isto é, se se justifica pelas circunstâncias, deixamos de considerá-la negativa em seu conjunto. Essa é a única razão para que a condenação criminal seja tolerável, se pensarmos em seu destinatário como um ser humano titular de imanente dignidade.

Definitivamente, não é a tônica dos tempos em que vivemos. A condenação, quase sempre, é comemorada como uma vitória. Vitória da sociedade, que com

\footnotetext{
${ }^{41}$ Encaixam-se com justeza as ponderações de Jean-Marie Müller: "Se, apesar de tudo, ocorrer a morte de um homem em virtude de acção policial, trata-se de um revés que proíbe qualquer "comunicado de vitória"'. IN: MÜLLER, Jean-Marie. O Princípio de Não-violência. Trad. Maria Fernanda Oliveira. Lisboa: Instituto Piaget, 1995, p. 130.

${ }^{42}$ WELZEL, Hans. Derecho Penal Alemán. Trad. Juan Bustos Ramírez y Sergio Yáñez Pérez. 4. ed., Santiago: Editorial Jurídica de Chile, 1997, p. 98.
} 
a ajuda de uma mídia sensacionalista, festeja abertamente a desgraça do outro, do vilão enfim derrotado. Vitória da justiça (ou "Justiça"?). A admiração por promotores e juízes, nomeados por uma sociedade carente seus paladinos, parece dar-se na proporção de suas atuações implacáveis no processo. Quanto mais ferrenha a acusação, ou quanto mais dura a sentença, mais confiável se apresenta o herói. Firme. Inflexível. Faz cumprir lei. Pelo menos uma parte dela.

Não se sugere, obviamente, que um juiz criminal viva submerso em depressão, por suas condenações; ou que um promotor de justiça batalhe perpetuamente contra crises existenciais pelas acusações que realiza; nem que a sociedade instaure verdadeiro luto pela desgraça que acomete 0 condenado. Aliás, nem mesmo se sugere que o condenado seja tratado como "coitado", ou que se transforme em alvo de pena (no sentido de piedade) ou condescendência. A questão é bem outra: não podemos romantizar as condenações criminais como desfechos felizes de histórias tristes. A condenação não é a última página do livro; marca, apenas, o fim de um capítulo. Pelo menos para o acusado, a história prossegue, e o trecho seguinte não será nada feliz $^{43}$. A consciência de que a condenação não constitui um encerramento, mas o início de uma trajetória de agruras, é essencial para evitar uma banalização. É preciso pensar constantemente no outro e dimensionar seu sofrimento, lembrando, sempre, que se trata de um semelhante. O condenado não é um monstro. Não é uma coisa. A perda dessa sensibilidade é desastrosa e deflagra um processo de gradual naturalização da violência. Por isso não devemos celebrar as condenações como algo bom ou "positivo em si". Porque não há violências contra seres humanos que sejam positivas. A justificação da condenação ou a demonstração racional da sua necessidade não tem o condão de fazê-la "um bem". Aliás, pensar na condenação de tal forma é algo extremamente perigoso. Aceitá-la à luz da necessidade de um caso concreto é muito diferente de vê-la como um bem a priori. Esse último pensamento foi certamente o que abriu espaço para o nazismo.

A aniquilação dos judeus e a crueldade dos campos de concentração somente contaram com altos índices de adesão por duas razões: porque 0 judeu foi descaracterizado como um semelhante, isto é, foi rebaixado da condição humana; e porque a "limpeza" traduziria um bem para o povo alemão. Além de eliminar aquela "raça nociva", o projeto nazista retomaria a riqueza para o povo alemão, que se via imerso em dificuldades. Se realmente acreditarmos na pureza desse discurso, como não julgar positiva a sua execução?

Alguma semelhança com a realidade brasileira? Ora, também elegemos nossos inimigos. O traficante, o "pedófilo" e o membro da "organização criminosa" são nossos judeus. Seu extermínio devolverá à sociedade a parcela da liberdade que Ihe foi roubada. Por isso, devemos combatê-los, declarar guerra

\footnotetext{
${ }^{43}$ Até mesmo para a própria vítima (ou seus familiares), aliás, nenhuma garantia de satisfação haverá. A condenação não reconstrói sua vida; apenas destrói a do violador. Se isso suscita prazer, não cremos que ele seja duradouro.
} 
ao tráfico e à pedofilia. O uso das expressões belicosas não é acidental: na guerra, abre-se o espaço para as medidas extremas e afrouxam-se os referenciais éticos. O que importa é vencer, a qualquer custo. Primeiro, demonizamos nossos inimigos, negando-lhes a condição humana. Depois, demonstramos o quanto é útil ou produtiva sua obliteração. Trilhando exatamente o mesmo trajeto do nazismo, passamos enxergar como boa uma violência naturalizada a partir das noções da coisificação e da utilidade. Em um quadro como esse, não é nenhum exagero esperar uma inversão de valores que transforme os direitos e garantias fundamentais em brechas de impunidade.

Já não são poucos os que, ao ouvir a expressão "defesa dos direitos fundamentais", desde logo se indignam para indagar: "mas e os direitos fundamentais da vítima?" Eis aqui um clássico emaranhado de confusões. Como registra David Garland ${ }^{44}$, "Expressões de preocupação com o criminoso e com suas necessidades sinaliza o desprezo pela vítima e seu sofrimento. A resposta padrão para aqueles que se mobilizam em favor dos direitos dos presos ou por melhor tratamento para os criminosos é que estes deveriam direcionar sua compaixão e preocupação para a vítima inocente e não para o criminoso culpado".

Lutar pelos direitos fundamentais significa sustentar o valor de todos os seres humanos, o que, obviamente, inclui tanto acusado quanto vítima. Defender os direitos do acusado não é negar os direitos da vítima, ou tampouco desprezar o dano por ela sofrido. É, apenas, uma tentativa de evitar uma segunda lesão. Porque se violou um direito da vítima, devemos aceitar a lesão aos direitos do acusado? É possível - na verdade, é necessário - zelar pelos dois. Ora, uma coisa não prejudica a outra. Do mesmo modo que massacrar o réu não significa prestigiar o ofendido (já que isso seguramente não restituirá a integridade do bem violado), respeitar os direitos do acusado não é desrespeitar a vítima. É preciso que assim seja porque, diferentemente daquilo que gostamos de acreditar, os papéis podem inverter-se a qualquer momento. Em um sistema penal hipertrofiado, a vítima de hoje pode muito bem ser o acusado de amanhã.

Garland ${ }^{45}$ externou sua perplexidade: "Como pode? Como os criminosos vieram a ser tão completamente despidos de toda a sua cidadania e dos direitos que a acompanham? Como uma preocupação excessiva pela "vítima" pôde sufocar qualquer consideração relacionada ao criminoso, como se ambas fossem categorias mutuamente excludentes?"

A explicação, o próprio autor sinaliza. Guarda relação com o que chamamos, linhas acima, de alienação criminogênica. Em seu dizer, deriva do "crescimento de uma divisão social e cultural entre 'nós' e 'eles"'. O criminoso é diferente, é estranho. Da vítima, porém, nos aproximamos. Primeiro, porque,

\footnotetext{
${ }^{44}$ GARLAND, David. A Cultura do Controle: crime e ordem social na sociedade contemporânea. Trad. André Nascimento. Rio de Janeiro: Revan, 2008, p. 384.

${ }^{45}$ Idem, ibidem, p. 386.
} 
a partir da difusão do medo pelos veículos midiáticos sensacionalistas, todos somos vítimas em potencial. Depois, porque a vítima integra o grupo dos "bons", do qual fazemos (na verdade, supomos fazer) parte. Ela é "inocente". Todos querem ser inocentes. Todos querem ser alvo de consideração.

É muito importante perceber que o crime não é a obra de um monstro, de um inumano, de um ser diferente. Muito pelo contrário: é uma obra essencialmente humana. Só se delinque por ser humano, e por descumprir as convenções humanas criminalizadoras. Como não há dúvida de que as criminalizações são ditadas por uma classe dominante, a maioria das transgressões é atribuída aos desfavorecidos ${ }^{46}$. São justamente os desfavorecidos, que se distanciam acentuadamente das posições mais proeminentes do corpo social, os que mais precisam de urgente reconhecimento. Aliás, muitos de seus crimes podem ser vistos como uma forma de busca pelo reconhecimento.

Podem ser, no dizer de Müller" ${ }^{47}$, "o meio de se fazer reconhecer para aqueles cuja existência permanece não só desconhecida, como não reconhecida. A violência é então o meio de se revoltar contra esse não reconhecimento É o último meio de expressão daqueles que a sociedade privou de todos os outros meios de expressão. Uma vez que não tiveram possibilidade de comunicar-se por meio da palavra, tentam exprimir-se por meio da violência. [...] A violência quer ser uma linguagem e exprime, em primeiro lugar, um sofrimento; é, então, um sinal de angústia que deve ser decifrado como tal pelos outros membros da sociedade. [...] E quanto mais é proibida pela sociedade, mais a violência permite o reconhecimento".

É claro que a busca de um reconhecimento, ou mesmo a exclusão, não justifica a violência. Podem ser motivos. Explicações. Mas é importante deixar bem claro: "compreender a violência não é motivo para a justificar. [...] $\mathrm{Na}$ realidade, a ideologia da violência permite a cada pessoa justificar a sua própria violência".

Em suma, é somente assim que prestigiaremos, de fato, os direitos fundamentais: afirmando sua universalidade. Eles são de todos. São nossos, mas são dos "outros". Assim, o criminoso, até então dessemelhante, tem conosco algo em comum. Esse primeiro estágio, embora incipiente, é condição de possibilidade da implementação de um Estado Democrático de Direito.

\footnotetext{
${ }^{46}$ Não pretendemos, definitivamente, vitimizar antecipadamente os pobres e aderir à "teoria da conspiração" que se constrói a partir do fanatismo sobre as ideias marxistas. Fazemos, apenas, uma constatação que reputamos inegável. A sociedade é multifacetada e a pluralidade de valores e interesses nunca permitiria a confecção de uma malha de crimes e sanções uniforme e cuja aprovação fosse unânime. Ela sempre será imposta por um grupo vitorioso. No caso, pelos que detêm o poder (não apenas econômico, embora ele seja relevante, mas também o político, religioso, intelectual, etc.).

${ }^{47}$ MÜLLER, Jean-Marie. O Princípio de Não-violência. Trad. Maria Fernanda Oliveira. Lisboa: Instituto Piaget, 1995, p. 34.

${ }^{48}$ Idem, ibidem, p. 35.
} 
Tornamos a frisar: reconhecer a humanidade do outro é uma atitude definitiva e de efeitos magnânimos. Se o réu passa a ser visto como um semelhante, já não posso mais desviar-me dele ou esquecê-lo: "O rosto impõe-se-me sem que possa parar de ser responsável pela sua miséria". Ao encontrar o outro homem, contraio uma obrigação [...]".

Para o próprio Estado interventor - especialmente se quiser manter seu projeto democrático - o respeito pela condição humana é essencial. Afinal, ele precisa "começar a dar exemplo de consideração da pessoa, se quiser fomentar uma atitude de respeito pelos demais". ${ }^{50}$

\section{CONSIDERAÇõES FINAIS}

Para tornar-se algo tolerável em um ambiente democrático, o sistema penal deve ser humanizado. Para isso, é preciso que adotemos algumas posturas.

A primeira delas é a de nunca esquecer que o sistema penal é uma violência tremenda. Que atingirá duramente direitos fundamentais do acusado e do condenado, e que existe com o exato propósito de infligir-lhes sofrimento. A pena deve ser vista como um mal necessário. Como uma medida destrutiva cuja necessidade não é capaz de convertê-la em algo positivo.

A segunda providência, ainda mais importante que a primeira, é a de estabelecer a consciência inarredável de que o réu é um ser humano digno e irrevogavelmente titular de direitos fundamentais. Independentemente do crime pelo qual esteja sendo acusado ou tenha sido condenado. Essencial, para isso, é o reconhecimento da semelhança. É só o que pode dar um fim à alienação criminogênica, que faz com que pensemos os crimes sempre como frutos das maldades e das falhas dos outros, os inimigos.

$\mathrm{Na}$ medida em que afirmamos a condição humana do réu, e que nos inteiramos da desgraça que é a submissão ao sistema prisional, somos obrigados a um agir responsável. Por eles, nossos semelhantes, e por nós mesmos. Desde que tenhamos adquirido essas percepções, teremos assumido, automaticamente, uma obrigação da qual não nos poderemos esquivar. Pois, "na realidade, perante uma injustiça, a passividade é uma atitude mais vulgar do que a violência". ${ }^{51}$

Precisamos, enfim, re-significar o réu. Nossa realidade constitucional não permite que sigamos tratando-o como coisa. Muito menos como coisa insignificante.

\footnotetext{
${ }^{49}$ MÜLLER, Jean-Marie. O Princípio de Não-violência. Trad. Maria Fernanda Oliveira. Lisboa: Instituto Piaget, 1995, p. 71.

${ }^{50}$ MIR PUIG, Santiago. Estado, Pena y Delito. Montevidéu: Editorial B de F, 2006, p. 74. "El Estado ha de empezar por dar ejemplo de consideración de la persona, si quiere fomentar una actitud de respeto por los demás". Tradução nossa.

${ }^{51}$ MÜLLER, Jean-Marie. O Princípio de Não-violência. Trad. Maria Fernanda Oliveira. Lisboa: Instituto Piaget, 1995, p. 21.
} 


\section{REFERÊNCIAS BIBLIOGRÁFICAS}

ANITUA, Gabriel Ignacio. Histórias dos Pensamentos Criminológicos. Trad. Sérgio Lamarão. Rio de Janeiro: Revan, 2008.

CARVALHO NETTO, Menelick de. Requisitos Pragmáticos da Interpretação Jurídica sob o Paradigma do Estado Democrático de Direito. Belo Horizonte: Mandamentos, 2000. Revista de Direito Comparado, v. 3, p. 473-486.

CORVAL, Paulo Roberto dos Santos. Teoria Constitucional e Exceção Permanente: uma categoria para a Teoria Constitucional no século XXI. Curitiba: Juruá, 2009.

FOUCAULT, Michel. Vigiar e Punir. Trad. Raquel Ramalhete. 20. ed., Petrópolis: Vozes, 1999.

GARLAND, David. A Cultura do Controle: crime e ordem social na sociedade contemporânea. Trad. André Nascimento. Rio de Janeiro: Revan, 2008.

GIRARD, René. A Violência e o Sagrado. Trad. Martha Conceição Gambini. 2. ed., São Paulo: Paz e Terra, 1998.

MIR PUIG, Santiago. Estado, Pena y Delito. Montevidéu: Editorial B de F, 2006.

MÜLLER, Jean-Marie. O Princípio de Não-violência. Trad. Maria Fernanda Oliveira. Lisboa: Instituto Piaget, 1995.

SARMENTO, Daniel. O Neoconstitucionalismo no Brasil: Riscos e Possibilidades. IN: Neoconstitucionalismo(s). Coord. QUARESMA, Regina et al. Rio de Janeiro: Forense, 2009, p. 267-302.

WELZEL, Hans. Derecho Penal Alemán. Trad. Juan Bustos Ramírez y Sergio Yáñez

Pérez. 4. ed., Santiago: Editorial Jurídica de Chile, 1997. 